\title{
CCL27 wt Allele
}

National Cancer Institute

\section{Source}

National Cancer Institute. CCL27 wt Allele. NCI Thesaurus. Code C49744.

Human CCL27 wild-type allele is located within 9p13 and is approximately $4 \mathrm{~kb}$ in length.

This allele, which encodes C-C motif chemokine 27 protein, is involved in the navigation of memory $T$ lymphocytes to cutaneous sites in inflammatory processes. 